\title{
Standarisasi produk dan strategi digital marketing untuk meningkatkan pemasaran pada UMKM VCO Bertuah
}

\author{
Sujarwati*, Siti Fatonah, Bernadeta Leni Fibriarti, Silvera Devi Sy, Oswati Hasanah, \& Arini \\ Universitas Riau \\ *sujarwati@lecturer.unri.ac.id
}

\begin{abstract}
Abstrak. VCO Bertuah adalah UMKM di Pekanbaru yang memproduksi minyak kelapa murni (virgin coconut oil). VCO Bertuah telah memiliki izin legalitas berupa IUMK, NIB dan Sertifikat P-IRT akan tetapi VCO Bertuah belum memiliki sertifikat halal, izin edar BPOM, dan SNI produk. Pemasaran produk VCO Bertuah lebih banyak dilakukan melalui online terutama melalui platform media sosial facebook dan instagram. Belum dilakukan strategi digital marketing lainnya seperti youtube dan website. Berdasarkan hasil kegiatan dapat disimpulkan bahwa UMKM memerlukan pendampingan untuk mengurus legalitas usaha. Sangat diperlukan komunikasi aktif UMKM dengan instansi pemerintah yang membidangi perizinan usaha. Kegiatan pendampingan telah berhasil meningkatkan pemahaman mitra terhadap prosedur pengurusan legalitas usaha. Kegiatan pendampingan sangat membantu mitra dalam menyiapkan kelengkapan dokumen persyaratan legalitas usaha. Kegiatan pendampingan meningkatkan pemahaman mitra tentang strategi digital marketing melalui website, instagram, dan youtube. Kegiatan pendampingan membantu mitra menyiapkan konten iklan berupa foto produk, desain feed instagram, video testimoni, dan copy writing iklan yang baik.
\end{abstract}

Kata kunci: digital, marketing, standarisasi, umkm, vco

\begin{abstract}
VCO Bertuah is an MSME in Pekanbaru that produces virgin coconut oil. Bertuah VCO has legality permits in the form of IUMK, NIB and P-IRT Certificate. However, Bertuah VCO does not have a halal certificate, BPOM distribution permit, and product SNI. The marketing of Bertuah VCO products is mostly done online, especially through social media platforms such as Facebook and Instagram. Other digital marketing strategies such as youtube and websites have not been carried out. Based on the results of the activity, it can be concluded that UMKM need assistance to take care of business legality. It is necessary to have active communication between UMKM and government agencies in charge of business licensing. Assistance activities have succeeded in increasing partners' understanding of the business legality management procedures. Assistance activities are very helpful for partners in preparing documents for business legality requirements. Assistance activities increase partners' understanding of digital marketing strategies through the website, instagram and youtube. Assistance activities help partners prepare advertising content in the form of product photos, instagram feed designs, video testimonials, and good ad copywriting.
\end{abstract}

Keywords: digital, marketing, standardization, umkm, vco

To cite this article: Sujarwati., S. Fatonah, B. L. Fibriarti., S. Devi Sy., O. Hasanah., \& Arini. 2020. Standarisasi produk dan strategi digital marketing untuk meningkatkan pemasaran pada UMKM VCO Bertuah. Unri Conference Series: Community Engagement 2: 234-240. https://doi.org/10.31258/unricsce.2.234-240

(C) 2020 Authors

Peer-review under responsibility of the organizing committee of Seminar Nasional Pemberdayaan Masyarakat 2020 


\section{PENDAHULUAN}

Virgin Coconut Oil (VCO) adalah minyak kelapa murni yang diekstrak dari santan tanpa melalui proses pemanasan. VCO memiliki komponen utama asam lemak rantai sedang (MCFA= Medium Chain Fatty Acid) antara lain asam laurat, asam kaprat dan asam myristat (Setiaji et al. 2012). Asam laurat memiliki banyak manfaat bagi kesehatan antara lain sebagai sumber energi, anti virus, anti bakteri, dan anti jamur (Karouw 2020). Oleh sebab itu, di kalangan masyarakat VCO banyak dimanfaatkan sebagai minuman kesehatan antara lain untuk penunjang diet penurunan berat badan, menurunkan kolesterol, membantu penyembuhan pada penderita diabetes melitus, serta meningkatkan daya tahan tubuh. VCO juga dimanfaatkan untuk pemakaian luar yaitu untuk mempercepat penyembuhan luka, melembutkan dan mencerahkan wajah, membantu penyembuhan jerawat, melembutkan kulit, meningkatkan kesuburan rambut dan mengatasi kerontokan rambut (Sujarwati et al. 2020). Kandungan antioksidan di dalam VCO berfungsi untuk mencegah penuaan dini dan menjaga vitalitas tubuh (Soekardi 2012).

Berdasarkan SNI 7381:2008, VCO dinyatakan sebagai minyak yang diperoleh dari daging buah kelapa (Cocos nucifera) tua yang segar dan diproses dengan diperas dengan atau tanpa penambahan air, tanpa pemanasan atau dengan pemanasan tidak lebih dari $60^{\circ} \mathrm{C}$ dan aman dikonsumsi manusia. Ciri-ciri VCO menurut SNI adalah sebagai berikut: bau khas kelapa segar dan tidak tengik, rasa khas kelapa segar, tidak berwarna hingga kuning pucat, kadar air maksimal 0,2\% (BSN 2008). Produksi VCO skala rumah tangga dapat dilakukan dengan metode fermentasi spontan, tanpa penambahan mikroba. Santan dibiarkan hingga terbentuk 3 lapisan yaitu: blondo, minyak, dan air. VCO dipisahkan secara manual, kemudian disaring menggunakan kertas saring dan kapas (Sujarwati et al 2020).

VCO Bertuah adalah sebuah brand minyak kelapa murni yang dikembangkan oleh UMKM dengan skala industri rumah tangga. UMKM ini berlokasi di Kelurahan Sidomulyo Barat, Kecamatan Tampan, Pekanbaru, Riau. Produk VCO Bertuah mulai dipasarkan pada bulan April 2018. VCO Bertuah telah memiliki izin usaha berupa IUMK (Izin Usaha Mikro Kecil) dengan NIB (Nomor Induk Berusaha) 9120117041508 tertanggal 10 Oktober 2019 dan ijin edar berupa SPP-IRT (Sertifikat Produksi Pangan Industri Rumah Tangga) dengan No: 197/05.17/DPMPTSP/I/2020 tertanggal 14 Januari 2020. VCO Bertuah belum memiliki sertifikat halal, ijin edar BPOM, serta belum pernah melakukan uji kualitas produk secara lengkap.

Digital marketing adalah pemasaran produk atau jasa yang dilakukan dengan media digital. Tujuan dari pemasaran ini adalah untuk menjangkau sebanyak-banyaknya target customer secara efisien, personal dan relevan (Alma 2014). Pada dasarnya ada 6 kategori yang termasuk kedalam digital marketing yaitu SEO, SEM, Content Marketing, SMM, Email Marketing dan PPC (Basu et al. 2012). Strategi pemasaran sangat penting agar produk yang dijual dapat lebih dikenal secara luas oleh masyarakat. (Tjiptono 2010). Penggunaan digital marketing sangatlah perlu untuk mempermudah dalam kegiatan pemasaran produk sehingga pemasaran lebih efektif dalam menjangkau customer (Assauri 2013). Pemasaran VCO Bertuah lebih banyak dilakukan secara online melalui facebook personal dan instagram. Belum dilakukan pemasaran online melalui platform digital lainnya misalnya melalui website dan youtube.

SPP-IRT telah memberikan legalitas yang cukup untuk memasarkan VCO Bertuah. Namun karena diedarkan sebagai produk pangan, di dalam labelnya tidak diperbolehkan mencantumkan manfaat VCO bagi kesehatan. Untuk pemasaran yang lebih luas, diperlukan ijin edar BPOM dengan kategori obat dan jamu. VCO Bertuah perlu mengurus sertifikat halal sebagai jaminan keamanan bagi konsumen. Untuk pengembangan produk dan pemasaran yang lebih baik pada UMKM VCO Bertuah, maka perlu dilakukan program pendampingan mengenai penerapan standarisasi produk. Pemasaran melalui sosial media facebook personal memiliki keterbatasan jangkauan, oleh sebab itu diperlukan strategi digital marketing yang lebih luas jangkauannya. Tujuan dilakukan kegiatan pengabdian ini yaitu menerapkan standarisasi produk dan strategi digital marketing untuk meningkatkan pemasaran pada UMKM VCO Bertuah. Sasaran dari kegiatan pengabdian ini adalah UMKM VCO Bertuah.

\section{METODE PENERAPAN}

Penerapan standarisasi produk berkaitan dengan regulasi pemerintah yang mengatur tentang legalitas usaha, ijin edar, sertifikasi halal, SNI produk, dan perlindungan HAKI Merek.Untuk itu, teknik penyelesaian masalah yang berkaitan dengan standarisasi produk adalah dengan membuka akses komunikasi antara mitra dengan instansi terkait yang membidangi hal tersebut serta membantu mitra menyiapkan dokumen yang dibutuhkan mitra untuk mengurus perijinan. 
Penerapan strategi digital marketing memerlukan masukan dari praktisi yang berpengalaman di bidang digital marketing. Beberapa hal yang perlu didiskusikan adalah bagaimana mengoptimalkan sosial media untuk memperluas jangkauan pemasaran, dan bagaimana memanfaatkan website untuk membangun data base konsumen secara mandiri.

\section{HASIL DAN KETERCAPAIAN}

UMKM VCO Bertuah mempunyai potensi untuk dikembangkan melalui peningkatan kapasitas dan kualitas produksi. Potensi pasar masih terbuka luas sebab hingga saat ini belum ada satu merek VCO yang menguasai pasar VCO di Riau. Konsumen VCO Bertuah tidak hanya dari lokal, tapi juga berasal dari luar Provinsi Riau antara lain Tanjung Pinang, Batam, Palembang, Jambi, Medan, Payakumbuh, Jakarta, Tangerang, Yogjakarta, Semarang, Demak, Sragen, Bojonegoro, Surabaya, Makasar. Produk VCO Bertuah diterima dengan baik oleh masyarakat. Lebih dari 50\% konsumen melakukan pembelian ulang (repeat order). Produknya memang bermanfaat, dibuktikan dengan banyaknya testimoni dari konsumen. VCO Bertuah termasuk produk yang diprioritaskan masyarakat meski kondisi perekonomian sedang tidak baik. Hal ini terbukti dengan meningkatnya penjualan VCO Bertuah selama terjadinya pandemi Covid-19.

Keberhasilan program diukur dengan membandingkan data awal, data pertengahan, dan data akhir (Tabel 1).

Tabel 1. Hasil pengukuran indikator ketercapaian kegiatan

\begin{tabular}{|c|c|c|c|c|c|}
\hline \multirow[b]{2}{*}{ No. } & \multirow[b]{2}{*}{ Indikator pengukuran } & \multirow{2}{*}{$\begin{array}{c}\text { Awal } \\
\text { Kegiatan } \\
\text { (Juni) }\end{array}$} & \multicolumn{2}{|c|}{ Tengah Kegiatan } & \multirow{2}{*}{$\begin{array}{c}\text { Akhir } \\
\text { Kegiatan } \\
\text { (September) }\end{array}$} \\
\hline & & & Juli & Agustus & \\
\hline 1. & $\begin{array}{l}\text { Pemahaman mitra tentang ijin edar VCO di } \\
\text { BPOM }\end{array}$ & 2 & 5 & 5 & 5 \\
\hline 2. & $\begin{array}{l}\text { Kelengkapan dokumen untuk mengurus ijin } \\
\text { edar BPOM }\end{array}$ & 1 & 1 & 1 & 2 \\
\hline 3. & $\begin{array}{l}\text { Pemahaman mitra tentang pengurusan } \\
\text { sertifikasi halal }\end{array}$ & 3 & 5 & 5 & 5 \\
\hline 4. & $\begin{array}{l}\text { Kelengkapan dokumen pengurusan sertifikasi } \\
\text { halal }\end{array}$ & 1 & 4 & 5 & 5 \\
\hline 5. & Pemahaman mitra tentang SNI VCO & 2 & 5 & 5 & 5 \\
\hline 6. & Kelengkapan dokumen pengurusan SNI VCO & 1 & 2 & 3 & 3 \\
\hline 7. & $\begin{array}{l}\text { Keseuain logo dan label kemasan dengan visi } \\
\text { misi mitra }\end{array}$ & 2 & 5 & 5 & 5 \\
\hline 8. & Pemahaman mitra tentang HAKI Merek & 1 & 5 & 5 & 5 \\
\hline 9. & $\begin{array}{l}\text { Kelengkapan dokumen pengurusan HAKI } \\
\text { Merek }\end{array}$ & 1 & 5 & 5 & 5 \\
\hline 10. & Ketersediaan foto produk untuk konten iklan & 2 & 4 & 5 & 5 \\
\hline 11. & $\begin{array}{l}\text { Kesesuain desain feed instagram dengan visi } \\
\text { misi mitra }\end{array}$ & 2 & 4 & 5 & 5 \\
\hline 12. & $\begin{array}{l}\text { Ketersedian artikel tentang VCO untuk konten } \\
\text { iklan }\end{array}$ & 1 & 5 & 5 & 5 \\
\hline 13. & $\begin{array}{l}\text { Adanya website untuk menunjang digital } \\
\text { marketing }\end{array}$ & 1 & 4 & 5 & 5 \\
\hline 14. & $\begin{array}{l}\text { Pemanfaatan instagram untuk pemasaran } \\
\text { produk }\end{array}$ & 2 & 4 & 5 & 5 \\
\hline 15. & Pemanfaatan youtube untuk pemasaran produk & 1 & 1 & 1 & 3 \\
\hline 16. & $\begin{array}{l}\text { Peningkatan omset dibanding bulan } \\
\text { sebelumnya }\end{array}$ & 5 & 1 & 5 & 5 \\
\hline 17. & Keterlibatan masyarakat sekitar lokasi UMKM & 1 & 1 & 1 & 3 \\
\hline
\end{tabular}

Keterangan: 1: sangat kurang, 2: kurang, 3: cukup, 4: baik, 5: sangat baik 
Tabel 1 menunjukkan bahwa sebelum dilakukan program pendampingan, pemahaman mitra tentang legalitas usaha masih kurang. Upaya untuk meningkatan pemahaman mitra terkait izin edar BPOM dilakukan melalui kegiatan diskusi dan konsultasi dengan Balai Besar POM (BBPOM) Pekanbaru (Gambar 1a). Kegiatan tersebut sangat bermanfaat untuk meningkatkan pemahaman mitra terkait izin edar BPOM untuk VCO. Izin edar BPOM untuk VCO dapat diajukan melalui dua kategori yaitu (1)kategori pangan dan (2)kategori obat dan jamu tradisional. Jika ijin edar VCO diajukan sebagai pangan, maka VCO diedarkan sebagai produk pangan dengan label MD (Makanan Dalam) dan tidak boleh beriklan dengan menyebutkan fungsi VCO bagi kesehatan. VCO juga dapat diajukan izin peredarannya pada kategori obat tradisional baik sebagai Usaha Kecil Obat Tradisional (UKOT) atau Usaha Mikro Obat Tradisional (UMOT). Untuk produksi sediaan VCO yang diminum, perijinaannya harus sebagai UKOT. Syarat minimal UKOT adalah berbentuk badan usaha minimal CV. Jika produksi sediaan VCO hanya untuk penggunaan luar, maka perijinan dapat diajukan sebagai UMOT. Perizinan sebagai UMOT dapat diajukan oleh perorangan, tidak harus berbentuk badan hukum.

Sampai dengan akhir kegiatan, kelengkapan dokumen persyaratan ijin edar BPOM tidak banyak mengalami kemajuan. Hal ini disebabkan karena pihak mitra belum memutuskan apakah izin edar VCO akan didaftarkan pada kategori pangan, UKOT, atau UMOT. Mitra berencana untuk mendaftarkan VCO BERTUAH sebagai UKOT sehingga langkah pertama adalah dengan mengurus badan usaha $(\mathrm{CV})$. Mitra belum mempunyai kesiapan dana, sarana dan prasarana untuk mengurus CV. Hal inilah yang menyebabkan persiapan dokumen izin edar BPOM belum bisa dikerjakan.

Sertifikasi Halal adalah suatu proses untuk memperoleh sertifikat halal melalui beberapa tahap untuk membuktikan bahwa bahan, proses produksi dan SJH memenuhi standar LPPOM MUI (Anonim 2014). Sertifikasi halal dilakukan oleh Badan Penyelengara Jaminan Produk Halal (BPJPH). BPJPH bekerjasama dengan Lembaga Pengkajian Pangan, Obat-obatan, kosmetik MUI (LPPOM-MUI) dan Majelis Ulama Indonesia (MUI) untuk penetapan kehalalan suatu produk (BPJPH Kementri Agama RI 2019).

Sebelum berlangsungnya kegiatan pengabdian, mitra telah mengikuti webiner tentang proses sertifikasi halal yang diadakan oleh Bank Indonesia bekerja sama dengan BPJPH dan LPPOM MUI pada tanggal 15 Mei 2020. Dengan mengikuti webiner ini, mitra terpilih sebagai salah satu UMKM yang mendapat bantuan pembiayaan sertifikasi halal dari Bank Indonesia. Di awal kegiatan pengabdian, mitra telah cukup memahami prosedur pengurusan sertifikasi halal. Kegiatan Tim Pengabdian adalah membantu untuk mengurus dokumen persyaratan sertifikat halal. Langkah pertama yang dilakukan adalah dengan mendampingi mitra berkonsultasi langsung ke BPJPH Kantor Wilayah Kementerian Agama Provinsi Riau (Gambar 1b). Hingga akhir kegiatan, semua dokumen persyaratan sertifikasi halal sudah selesai. Dokumen persyaratan sertifikasi halal untuk UMKM VCO Bertuah telah disusun sesuai prosedur (LLPOM MUI 2018) dan persyaratan sertifikasi halal (LPPOM MUI 2020). Karena mitra telah terdaftar sebagai binaan Bank Indonesia untuk proses sertifikasi halal, maka untuk selanjutnya proses sertifikasi halal akan dibimbing oleh Bank Indonesia yang bekerja sama dengan Lembaga Jaminan Halal UIN Suska Riau.

Standar Nasional Indonesia (SNI) adalah standar yang ditetapkan oleh Badan Standardisasi Nasional dan berlaku secara nasional. Badan Standardisasi Nasional (BSN) merupakan lembaga pemerintah nonkementerian Indonesia dengan tugas pokok mengembangkan dan membina kegiatan standardisasi di Indonesia (BSN 2020). Pada awal kegiatan, mitra belum memahami bagaimana SNI untk produk VCO. Oleh sebab itu, Tim Pengabdian mendampingi mitra berdiskusi dan konsultasi tentang SNI VCO ke Kantor Layanan Teknis BSN Pekanbaru untuk memperoleh informasi tentang SNI VCO (Gambar 1c). Dari diskusi dan konsultasi diperoleh informasi bahwa untuk VCO termasuk kedalam SNI yang bersifat sukarela. Pengurusan SNI VCO tidak diwajibkan pada pelaku usaha yang memproduksi VCO. Proses implementasi atau penerapan sesuai SNI dapat dilakukan oleh pelaku usaha tanpa perlu menjalani prosedur sertifikasi. Dengan adanya informasi ini, maka mitra tidak melanjutkan proses penyusunan dokumen persyaratan SNI. Namun, mitra tetap berusaha memenuhi standar kualitas produk sesuai SNI VCO yaitu SNI 7381:2008 (BSN 2008). Untuk itu, mitra telah mengirim sampel VCO untuk uji kualitas produk ke Balai Pengembangan Produk dan Standarisasi Industri (BPSI) Pekanbaru dan Laboratorium Jasa Pengujian, Kalibrasi dan Sertifikasi, IPB. Berdasarkan hasil uji BPSI Pekanbaru, VCO Bertuah telah memenuhi syarat mutu VCO berdasarkan SNI 7381 : 2008 dengan hasil uji sebagai berikut: bau dan rasa khas kelapa, tidak berwarna, kadar air 0,084\% dan kadar asam lemak bebas $0,28 \%$.

Logo merupakan bagian dari identitas brand yang dapat dikenali oleh penglihatan manusia melalui dua ciri khas utama yaitu identitas warna dan identitas bentuk logo tersebut (Irwan 2020). Sebelum dilakukan kegiatan, mitra telah memiliki logo. Namun, mitra memiliki keinginan untuk mendiskusikan kembali logo tersebut agar lebih tepat dan menggambarkan misi visi mitra. Tim pengabdian mendampingi mitra berdiskusi tentang logo 
dan kemasan dengan Konsultan UPT Konsultasi logo dan kemasan ke UPT Klinik Kemasan Disperindag Pekanbaru. Hasil diskusi tersebut didapatkan desain logo dan label kemasan yang baru. Logo VCO Bertuah merupakan perpaduan antara gambar dan tulisan. Gambar berbentuk hati berwarna merah dengan tanda cheklist di atas. Gambar ini merupakan simbol bahwa VCO Bertuah diproduksi dengan sepenuh hati. Pelayanan kepada konsumen dilakukan tulus dari hati. Tanda checklist mengandung arti produk VCO BERTUAH memenuhi standar mutu.

Merek "VCO Bertuah" belum didaftarkan ke Direktorat Jenderal Kekayaan Intelektual. Tim Pengabdian mendampingi mitra untuk berkonsultasi tentang prosedur pendaftaran merek ke kantor Kantor Wilayah Kementerian Hukum dan HAM Provinsi Riau (Gambar 1d). Tim Pengabdian mendorong mitra untuk mengikuti program bantuan biaya pengurusan HAKI Merek kerja sama antara Kantor Wilayah Kementerian Hukum dan HAM Provinsi Riau dan Dinas Perindustrian, Perdagangan, dan Koperasi, Usaha Kecil dan Menengah Provinsi Riau. Pada akhir kegiatan, semua dokumen persyaratan pendaftaran HAKI Merek sudah selesai dan sudah diserahkan ke Direktorat Jenderal Kekayaan Intelektual Kantor Wilayah Kementerian Hukum dan HAM Provinsi Riau

Strategi digital marketing yang dilakukan dalam kegiatan ini adalah pembuatan website, optimasi instagram dan youtobe. Tim Pengabdian membantu mitra menyediakan foto produk yang baik, video testimoni, desain feed instagram yang sesuai dengan visi misi mitra, serta artikel tentang VCO untuk konten iklan.

Kegiatan pengabdian dilaksanakan selama tiga bulan yaitu bulan Juli-September 2020. Hasil akhir kegiatan berupa kelengkapan dokumen persyaratan sertifikasi halal, hasil uji kualitas produk VCO, logo dan label kemasan yang baru, pendaftaran HAKI Merek VCO Bertuah, foto produk, desain feed instagram, buku marketing kit VCO Bertuah, website dengan alamat https://www.vcoBertuah.com, akun instagram www.instagram.vcoBertuah yang lebih teroptimasi, dan video yang diunggah di akun youtube Rumah Kreatif Bertuah.

Hasil akhir kegiatan ini secara langsung belum dapat diukur pengaruhnya terhadap peningkatan pemasaran dan omset VCO Bertuah. Namun data menarik dijumpai pada omset VCO Bertuah selama pelaksanaan kegiatan. Pada bulan Juli 2020, terjadi penurunan omset sebesar 46\% dibandingkan omset bulan Juni 2020. Sedangkan pada bulan Agustus 2020, terjadi peningkatan omset sebesar 48\% dibandingkan omset bulan Juli 2020.

Diharapkan dampak dari kegiatan ini dapat bersifat berkesinambungan. Dengan diterbitkannya Sertifikat Halal dan HAKI Merek VCO Bertuah serta hasil uji laboratorium yang memenuhi SNI VCO, diharapkan VCO Bertuah dapat ditingkatkan pemasarannya lebih luas melalui strategi digital marketing. Perluasan jangkauan pemasaran harus didukung oleh peningkatan kapasitas produksi. Oleh sebab itu, Tim Pengabdian mendorong mitra untuk menambah jumlah tenaga dengan melibatkan warga sekitar lokasi produksi dengan cara membentuk Kelompok Usaha Bersama. Dengan demikian, peningkatan omset VCO Bertuah akan membawa dampak nyata pada perbaikan kehidupan masyarakat sekitar.
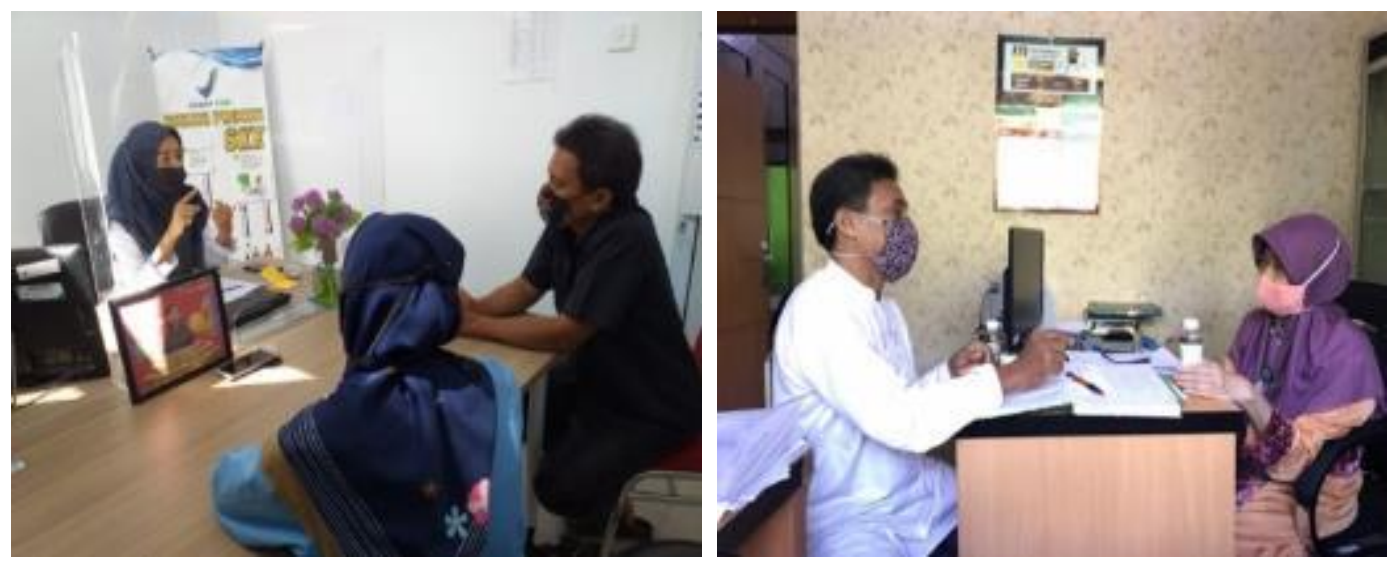

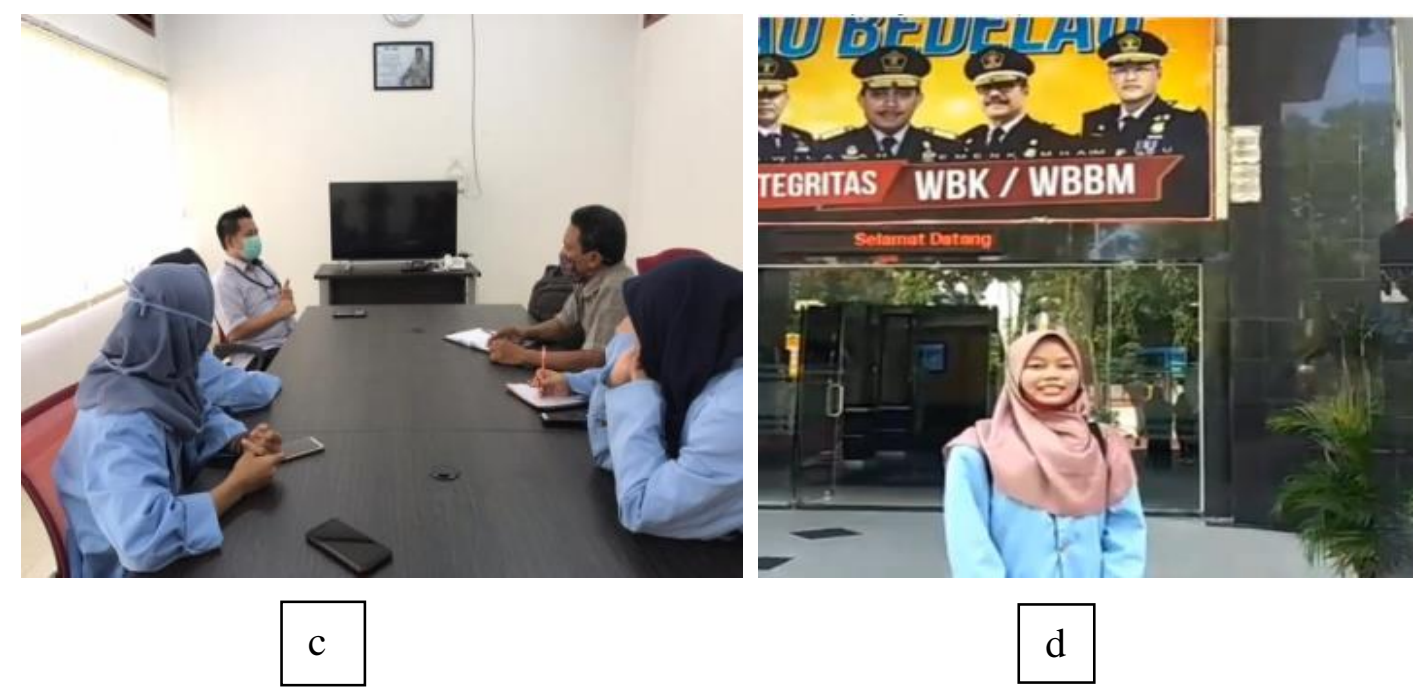

Gambar 1. Diskusi dan konsultasi tentang ijin edar BPOM (a), sertifikat halal (b), VCO (c) dan HAKI Merek (d)

\section{KESIMPULAN}

Berdasarkan hasil kegiatan dapat disimpulkan bahwa UMKM memerlukan pendampingan untuk mengurus legalitas usaha. Sangat diperlukan komunikasi aktif UMKM dengan instansi pemerintah yang membidangi perizinan usaha. Kegiatan pendampingan telah berhasil meningkatkan pemahaman mitra terhadap prosedur pengurusan legalitas usaha. Kegiatan pendampingan sangat membantu mitra dalam menyiapkan kelengkapan dokumen persyaratan legalitas usaha. Kegiatan pendampingan meningkatkan pemahaman mitra tentang strategi digital marketing melalui website, instagram, dan youtube. Kegiatan pendampingan membantu mitra menyiapkan konten iklan berupa foto produk, desain feed instagram, video testimoni, dan copy writing iklan yang baik.

\section{UCAPAN TERIMA KASIH}

Terima kasih disampaikan kepada Ketua LPPM Unri atas dukungan dan dana yang diberikan melalui Skema Pengabdian Kepada Masyarakat, Dana DIPA Unri Tahun 2020 dengan Nomor Kontrak: 891/UN.19.5.1.3/PT.01.02/2020. Ucapan terima kasih juga disampaikan kepada Lurah Sidomulyo Barat dan UMKM VCO Bertuah sebagai mitra dalam kegiatan pengabdian ini. Ucapan terima kasih dan rasa bangga disampaikan kepada Tim Mahasiswa Kukerta Terintegrasi-Pengabdian Masyarakat LPPM UNRI Tahun 2020 yang telah banyak membantu sehingga kegiatan ini dapat berjalan dengan baik.

\section{DAFTAR PUSTAKA}

Alma, B. 2014. Manajemen Pemasaran dan Pemasaran Jasa. Alfabeta. Bandung.

Anonim. 2014. Undang - Undang No.33 Tahun 2014 Tentang Jaminan Produk Halal.

Assauri, S. 2013. Manajemen Pemasaran: Dasar Konsep dan Strategi. Rajawali Pers. Jakarta.

Badan Standarisasi Nasional (BSN). 2008. Standar Mutu Minyak Kelapa Murni. SNI 7381:2008. Jakarta.

Basu, S. Dan Irawan, H. 2012. Manajemen Pemasaran Modern Edisi Ke-2. Liberty Offset. Yogyakarta.

BPJPH Kementri Agama RI. 2019. Sertifikasi Halal. http://www.halal.go.id/layanan/sertifikasi. (diakses tanggal 23 Juli 2020).

BSN. 2020.Perumusan SNI. https://www.bsn. go.id/main/bsn/isi_bsn/20169/peru-musan-sni. Diakses tanggal 26 Juli 2020.

Irwan, G. 2020. 10 Jenis dan Filosofi Desain Logo Brand. https://www.glngirwn.com/blog/jenis-filosofi-logo/. Diakses pada tanggal 18 September 2020.

Karouw S. 2020. Manfaat Kesehatan Virgin Coconut Oil dan Minyak Kelapa. Disampaikan pada Webiner: "Manfaat Kesehatan VCO dan Minyak Kelapa di Masa Pandemic Covid-19”. 14 Mei 2020. 
LPPOM MUI. 2018. Prosedur Sertifikasi Halal MUI. htttps://www.halalmui.org/mui14/main/page/prosedur-sertifikasihalal-mui. Diakses tanggal 22 Juli 2020.

LPPOM MUI. 2018. Prosedur Sertifikasi Halal MUI. htttps://www.halalmui.org/mui14/main/page/prosedur-sertifikasihalal-mui. Diakses tanggal 22 Juli 2020.

LPPOM MUI. 2020. Persyaratan Sertifikasi Halal MUI. https://www.halalmumui.org/mui14/main/page/persyartaansertifikasi-halal-mui. Diakses pada tanggal 22 Juli 2020.

Setiaji, B. Dan S. Prayugo. 2006. Membuat VCO berkualitas Tinggi. Penebar Swadaya. Jakarta.

Soekardi, Y. 2012. Pemanfaatan dan Pengolahan Kelapa Menjadi Berbagai Bahan Makanan dan Obat Berbagai Penyakit. Yrama Widya. Bandung.

Sujarwati, S. Fatonah, B.L. Fibriarti, S. Devi Sy, O. Hasanah, Arini. 2020. Bertuahnya VCO: Produk Sederhana, Kaya Manfaat. Penerbit Taman Karya. Pekanbaru.

Tjiptono, F. 2010. Strategi Pemasaran, Edisi 2. Andi Offset. Yogyakarta. 